\title{
ПРОФЕССИОНАЛЬНАЯ ИДЕНТИЧНОСТЬ СТУДЕНТОВ, ПОЛУЧАЮЩИХ ПРОФЕССИОНАЛЬНОЕ ОБРАЗОВАНИЕ (НА ПРИМЕРЕ ВЫСШЕГО ОБРАЗОВАНИЯ)
}

\begin{abstract}
АННОТАЦИЯ. В статье раскрываются особенности профессиональной идентичности у студентов-бакалавров г. Иркутска третьего года обучения по направлениям подготовки прикладная информатика, архитектура, логистика и менеджмент на транспорте, государственное и муниципальное управление. Респондентам было предложено оценить себя и типичных представителей некоторых профессий (информатик, логист, архитектор, государственный служащий и врач) по шкалам Личностного дифференциала Осгуда адаптированным в НИИ им. В. М. Бехтерева. Количество значимых различий между образами «Я» и образа представителя своей профессий у исследованных студентов сопоставимы с количеством значимых различий между образом «Я» и образами представителей других профессий. Образ «Я» у всех студентов в целом оценивается более позитивно в сравнении с образами типичных представителей профессий. Можно сказать, что образ «Я» скорее равноудален от всех оцениваемых респондентами профессий. Исследованная нами выборка студентов третьего курса бакалавриатуры дает основания предположить, что идентичность участников исследования на момент исследования строится не столько по профессиональному вектору развития, а скорее по социальному. То есть идентификация себя идет скорее, как «студент» нежели как «представитель профессии».

КЛЮЧЕВЫЕ СЛОВА. Личностная и профессиональная идентичность; профессиональная идентичность студентов; образ Я; становление профессиональной идентичности бакалавров.

ИНФОРМАЦИЯ О СТАТЬЕ. Дата поступления 10 октября 2016 г.; дата принятия к печати 2 ноября 2016 г.; дата онлайн-размещения 30 ноября 2016 г.
\end{abstract}

V. N. Mungalov Baikal State University, Irkutsk, Russian Federation

A. G. Levina

Baikal State University,

Irkutsk, Russian Federation

\section{PROFESSIONAL IDENTITY OF STUDENTS OBTAINING HIGHER PROFESSIONAL EDUCATION}

\begin{abstract}
The article reveals the features of professional identity of bachelor students of the third year of studies in Irkutsk in the direction of applied computer science, architecture, transport logistics and management, governmental and municipal management. Respondents were offered to assess themselves and typical representatives of some professions (information scientist, logistician, architecture, governmental officer and doctor) according to the scales of the Ostud Personal Differential adapted in V. M. Bekhterev Research Institute. The number of significant differences between the images «I» and the image of the own profession representative gained from investigated students are consistent with the number of significant differences between the images «I» and images of other profession representatives.
\end{abstract}

(C) В. Н. Мунгалов, А. Г. Левина, 2016

\section{Baikal Research Journal}


The image «I» of all students is, on the whole, assessed more positively in comparison to images of typical representatives of professions. One can say that the image "I" is equidistant from all professions assessed by the respondents. The selection of the third-year bachelor students in our investigation gives reasons to suppose that the identity of the investigation participants at the moment of the investigation is built not rather according to the professional development vector but sooner to the social one. That is, the identification of oneself involves rather «being a student» than «being a representative of a profession».

KEYWORDS. Personal and professional identity; students' professional identity; image «I»; establishing professional identity of bachelors.

ARTICLE INFO. Received October 10, 2016; accepted November 2, 2016; available online November 30, 2016.

Рост интереса к проблемам идентичности, не только профессиональной, но и личностной, этнической или гражданской в нашей стране на протяжении последних десятилетий XX и начала XXI в. не ослабевает. По справедливому наблюдению Т. Г. Стефаненко на процессы поиска идентичности влияют как общемировые факторы (развитие процессов глобализации, строительство модели мировой экономики, а также различных информационных сетей мирового масштаба), и региональные факторы, связанные с процессами в конкретной части мира (распад конкретных государств, смена политических элит, государственного устройства и др.) [1]. Распад Советского Союза, исчезновение преемственности в процессе воспитания гражданина (через институты подобные в СССР: октябрята - пионерия - комсомол - компартия) обусловили потерю населением бывших союзных республик привычных для социалистического общества позитивных моделей идентичности (рабочий, колхозник, ученый, врач и др.). Вместе с этим переход к рыночной экономической модели, снижение общего уровня благосостояния населения вместе с отсутствием четких социальных ориентиров в переходный период, рост преступности и асоциальных форм поведения поставили перед гражданами России острые вопросы экзистенциального характера: «Кто Я?», «Для чего живу?» и «Как жить дальше?». Поиски ответов на них спровоцировало разные группы населения объединяться (в партии, церковные организации, неформальные объединения молодежи, преступные группировки и пр.), создавать подходящее описание изменившегося мира для повышения әффективности своего функционирования. В XXI в. новые вызовы вставшие перед Россией на фоне увеличения стабильности внутри страны способствуют постепенному упорядочиванию процессов поиска идентичности. Однако, проблема идентичности не теряет свою актуальность и по сей день.

Изучение проблемы идентичности в научном сообществе идет по нескольким направлениям: осмысление самого понятия идентичность, выявление структуры идентичности, типов идентичности, видов идентичности. Причем этим вопросом занимаются философы, социологи, психологи, культурологи, экономисты, управленцы, юристы, политологи. В психологии помимо привычных для конца XX в. исследований на темы этнической идентичности (Т. Г. Стефаненко, М. Т. Шергалиева, Е. Л. Трофимова), личностной и социальной идентичности (Д. А. Леонтьев, О. С. Анисимов, И. Н. Шаповал, О. В. Лукьянов [2]), профессиональной идентичности (В. Л. Цветков, Ю. В. Слободчикова, Л. Б. Шнейдер, Е. А. Климов), идентичности подростков (О. В. Гребенникова, Т. Г. Бохан [3], Н. В. Твердохлебова) в последние годы развиваются направления по изучению религиозной идентичности (Н. Л. Балич), городской и сельской идентичности (Н. С. Дягилева, Л. А. Журавлева, В. И. Гутыра), корпоративной идентичности (В. А. Нагоркин), региональной идентичности (Р. В. Борисов, Н. Ш. Акаева), гражданской

\section{Baikal Research Journal}

электронный научный журнал Байкальского государственного университета 
идентичности (Н. А. Галактионова, Е. Л. Трофимова), организационно-групповой идентичности (К. В. Злоказов), территориальной идентичности (И. А. Скалабан, О. А. Серебрянникова).

Цель данной статьи: представить общий сравнительный анализ профессиональной идентичности у студентов старших курсов бакалавриата получающих высшее профессиональное образование.

Не вдаваясь в анализ содержания понятия «идентичность» у разных исследователей и их подходов (это тема для отдельной статьи), хотелось бы тезисно описать исследовательский подход которым мы руководствовались в нашем исследовании. Вслед за Келли мы считаем, что человек существо, познающее $[4 ; 5]$. Человек в условиях огромного количества информационных потоков вынужден создавать инструменты для упорядочивания информации и работы с нею. Такими инструментами становятся шкалы оценки (конструкты в терминологии Келли), согласно которым человек становится способен ориентироваться в окружающем мире. Шкалы оценки человек может создавать сам, но огромное их разнообразие становится возможным благодаря заимствованию шкал оценки из социальной реальности. Благодаря шкалам оценки человек строит свое ментальное пространство в котором эти шкалы подбираются в соответствии с решаемой проблемной ситуацией. Сами шкалы в ментальном пространстве существуют в виде комплексов-представлениях о социальных моделях поведения. В своей повседневной ситуации человек использует привычный для него набор шкал оценки (идентифицируется с ним). Однако, в проблемной ситуации, когда они перестают способствовать решению текущих задач и эффективность функционирования человека снижается, встает вопрос подбора других шкал (поиска новой идентичности).

Идентичность выступает на наш взгляд с двух сторон: как задача на самоопределение и как задача на решение текущих проблем. Эти две стороны-задачи имеют две принципиально разных позиции исследования. Поэтому требуют и специфических инструментов для их решения. Задача на самоопределение предполагает наличие двух вводных: некий идеальный образ (профессии, себя, представителя той или иной группы) и оценку себя относительно этого образа по заданным шкалам. В результате при подобном сопоставлении в зависимости от идеального образа и выбранных шкал итоговая оценка человеком своих характеристик будет меняться. В этом типе задач внимание человека захвачено самооцениванием и сознание работает рефлексивно. В рамках этой задачи человек идентифицирует себя примерно также как происходит идентификация образа восприятия, примерно по следующей схеме: «у этой фигуры стороны равны, располагаются под прямым углом и в одной плоскости, значит, это квадрат».

Другая сторона-задача - решение текущих проблем. Так, например, для решения проблем управления коллективом человеку нужно принять модель поведения управленца. То есть, сам управленцем он может и не был никогда, однако, текущая ситуация жизни требует именно такой модели поведения. В данной ситуации человек пытается встроится, соотнести себя с этой моделью поведения, отождествится с нею, а значит, идентифицироваться с выбранной ролью. В этой ситуации вопрос самоопределения не стоит. Человек отказывается от имеющихся представлений о себе. На время решения проблемы он принимает новые, до некоторой степени чуждые ему прошлому модели поведения в пользу известных ему социальных ролей. Внутри этой роли человеку предоставляется возможность открыть или развить в себе новые качества. В данном типе задач внимание человека зафиксировано на задаче и сознание работает режиме познания. Здесь отсутствует четкое самоопределение в отличии от задачи первого типа.

\section{Baikal Research Journal}

электронный научный журнал Байкальского государственного университета 
По мнению Ю. П. Поваренкова, «выделение профессиональной идентичности является закономерным процессом последовательной дифференциации понятия «идентичность», поскольку в основе данного процесса лежит специфика ее элементов» [6, с. 54]. Исследователь рассматривает профессиональную идентичность как критерий профессионального развития.

Е. А. Климов рассматривает профессиональную идентичность в контексте проблематики профессионального самосознания [7]. «Профессиональная идентификация - это объективное и субъективное (т. е. данное в переживании) единство с профессиональной группой, делом, отдельным человеком, которое обусловливает преемственность профессиональных характеристик (норм, ролей и статусов) личности" [Там же, с. 158].

Л. Б. Шнейдер анализирует профессиональную идентичность как функциональное и экзистенциальное соответствие человека и профессии [8]. Профессиональная идентичность, по мнению автора, - «это не только осознание своей тождественности с профессиональной общностью, но и ее оценка, психологическая значимость членства в ней, разделяемые профессиональные чувства, своеобразная ментальность, ощущение своей профессиональной компетентности, самостоятельности и самоэффективности, т. е. переживание своей профессиональной целостности и определенности» [Там же, с. 103].

В психологии можно встретить два основных подхода к рассмотрению профессиональной идентичности: как компонент личностной идентичности [9] либо как вид социальной [10].

Также проблема становления профессиональной идентичности не остается без внимания исследователей [11]. Здесь основное внимание уделяется молодежи, получающей профессиональное образование и молодым сотрудникам на первых этапах своей профессиональной деятельности. Так, например, исследование Е. Л. Трофимовой студентов-психологов показало, что практические навыки и умения, по мнению самих студентов, сформированы недостаточно и готовности к реализации их в деятельности пока нет [11]. В своем исследовании мы решили выйти за рамки психологических специальностей и взглянуть на представителей других профессий.

В предлагаемом вашему вниманию результатам исследования профессиональной идентичности был проведен анализ «образа Я» у студентов-бакалавров третьего года обучения и образа типичного представителя профессии. Испытуемым предлагалось по шкалам личностного семантического дифференциала Осгуда [12] оценить себя и типичного представителя предложенных профессий (информатик, логист, архитектор, госслужащий, врач). После этого проводился анализ полученных данных на предмет выявления значимых различий между характеристиками образов себя и типичного представителя своей профессии, а также образа себя и типичных представителей других профессий.

Цель исследования показать специфику формирующейся профессиональной идентичности у студентов-бакалавров старших курсов.

Гипотезы исследования сформулированы так:

1. Образ себя и образ типичного представителя своей профессии не должны иметь значимых различий по большинству шкал оценки. Предполагается, что в процессе профессиональной подготовки студенты знакомятся с качествами, которые должны быть у представителей профессии, по которой они проходят подготовку, и развивают эти качества. То есть при эффективной подготовке образ себя и образ типичного представителя своей профессии к концу обучения не должны иметь значимых различий.

\section{Baikal Research Journal}

электронный научный журнал Байкальского государственного университета 
2. Образ себя и образ типичного представителя других профессий будут иметь значимые различия по большинству шкал оценки. Данное предположение имеет чисто гипотетическое предположение. Так как обучение по своему направлению подготовки предполагает формирование образа профессии более полно. Образ же других профессий остается на обыденном уровне.

В исследовании приняло участие 168 студентов-бакалавров третьего года обучения трех вузов г. Иркутска по четырем направлениям подготовки: прикладная информатика (Иркутский государственный университет, 42 человека), архитектура (Иркутский научный исследовательский технический университет, 42 человека), логистика и менеджмент на транспорте (Иркутский научный исследовательский технический университет, 42 человека), государственное и муниципальное управления (Байкальский государственный университет, 42 человека). Исследование проводилось во втором семестре третьего года обучения, т. е. до окончания подготовки студентам оставалось проучиться чуть более одного года.

На рис. 1-4 представлены средние значения по шкалам личностного семантического дифференциала Осгуда при оценке образа себя и типичного представителя своей профессии.

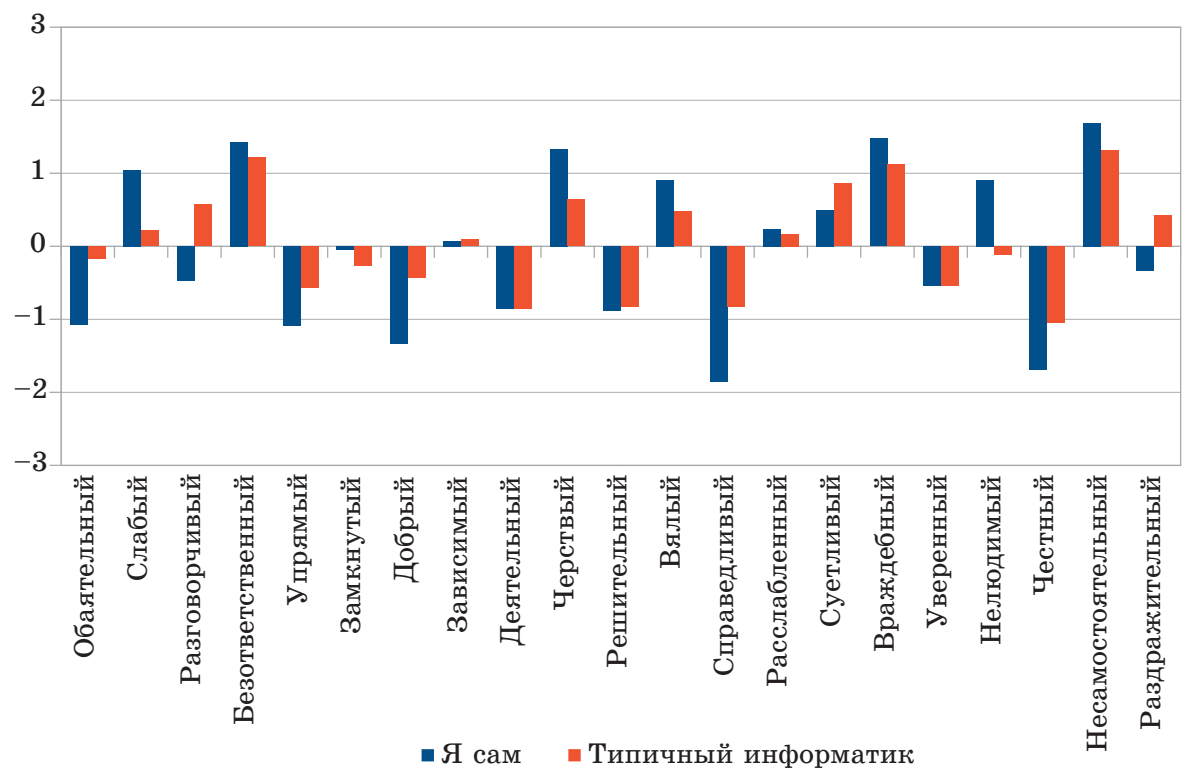

Рис 1. Образ себя и типичного информатика у студентов направления подготовки «Прикладная информатика»

Как видно из рис. 1 образы «Я сам» и «Типичный информатик» у студентов прикладной информатики третьего года обучения в отношении содержания качеств в целом идентичны. Исключение составляют показатели трех шкал. По ним студенты себя считают разговорчивыми, общительным, раздражительными, а информатика скорее молчаливым, нелюдимым, невозмутимым. При проверке различий по представленным шкалам на предмет значимых при помощи U-критерия Манна-Уитни было выявлено девять шкал (из 21) со значимыми различиями. Ими стали шкалы, описывающие обаятельность, силу, разговорчивость-молчаливость, доброту, справедливость, общительность-нелюдимость (на 0,01 уровне значимости) и отзывчивость, честность, раздражительность-невозмутимость (на

\section{Baikal Research Journal}


0,05 уровне значимости). Причем студенты прикладной информатики считают себя обаятельнее, сильнее, разговорчивее, добрее, справедливее, общительнее, отзывчивее, честнее и раздражительнее нежели «типичный информатик». В целом образ себя и образ информатика респонденты оценивают в позитивном ключе, причем считают, позитивные черты им присуще больше чем информатикам-практикам. Таким образом, первая гипотеза на выборке студентов прикладной информатики получила свое подтверждение.

У студентов логистики и менеджмента на транспорте (см. рис. 2) расхождения в образах себя и типичного логиста касаются только шкалы раздражительность-невозмутимость. Так себя они считают раздражительными, а логистов невозмутимыми. В остальных показателях образы «Я сам» и «Типичный Логист» идентичны. Также как и у предыдущей выборки, при проверке различий по представленным шкалам на предмет значимых при помощи U-критерия Манна-Уитни было выявлено девять шкал (из 21) со значимыми различиями. Это шкалы описывающие разговорчивость, деятельность, решительность, энергичность, уверенность, общительность, раздражительность-невозмутимость $(0,01$ уровень значимости) и упрямство, независимость ( 0,05 уровень значимости). Причем эта разница не в ползу студентов. Респонденты считают, что типичный логист превосходит их по этим показателям. В целом образы себя и типичного логиста позитивны. Таким образом, первая гипотеза на выборке студентов логистики и менеджмента на транспорте получила свое подтверждение.

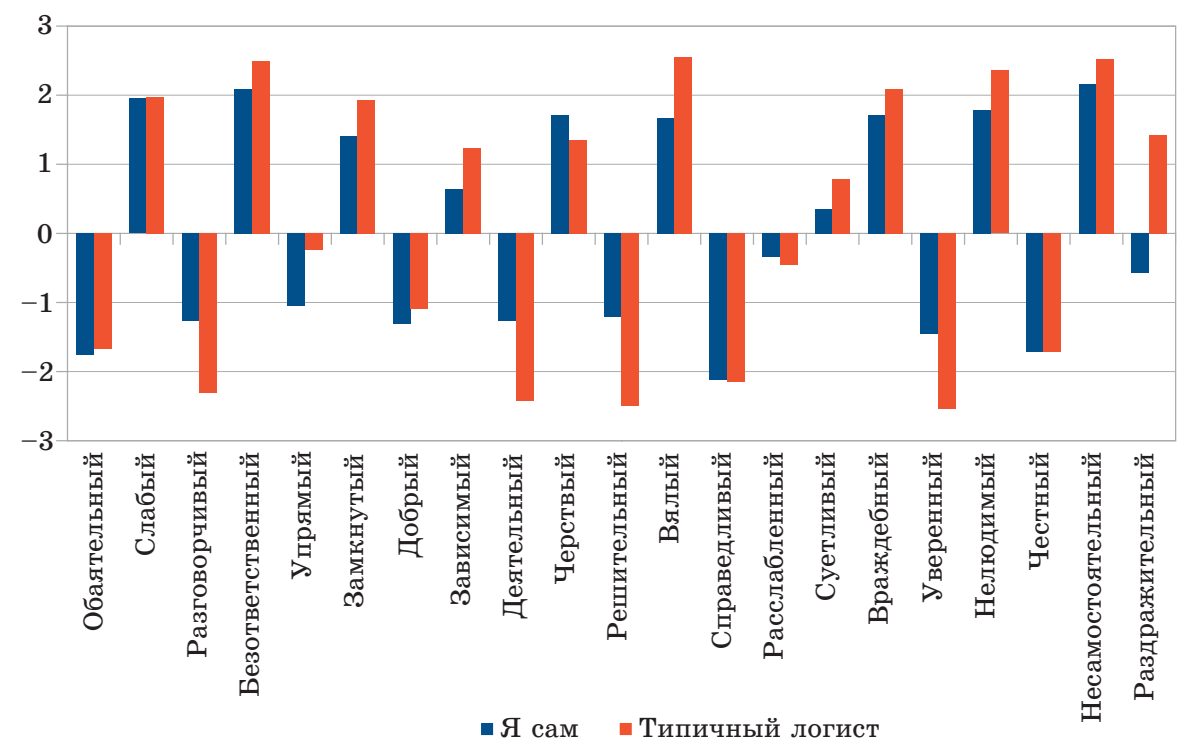

Рис. 2. Образ себя и типичного логиста у студентов направления подготовки «Логистика и менеджлент на транспорте»

На рис. 3 представлены средние значения по шкалам личностного дифференциала Осгуда в оценке образа себя и типичного архитектора в представлении студентов третьего курса направления архитектура. По заверениям самих студентов они на момент исследования испытывали разочарование в отношении выбранного направления обучения. Без сомнения, данный настрой не мог не сказаться на ответах. Так по 10 шкалам оценки образа себя респонденты оценили предложенные качества в значениях близкими к 0 в отличии от образа типичного архитектора. Это как раз и может говорить о разворачивающемся кризисе идентичности, когда

\section{Baikal Research Journal}


респондент с трудом определяет свои качества. Однако, несмотря на это образы «Я сам» и «Типичный архитектор» имеют высокую степень схожести за исключением значений по шкале раздражительность-невозмутимость, по которой ситуация аналогична в предыдущих двух выборках. Студенты считают архитектора невозмутимым, а себя раздражительными. Кризис идентичности у студентов-архитекторов виден и при проверке различий по представленным шкалам на предмет значимых при помощи $U$-критерия Манна-Уитни.

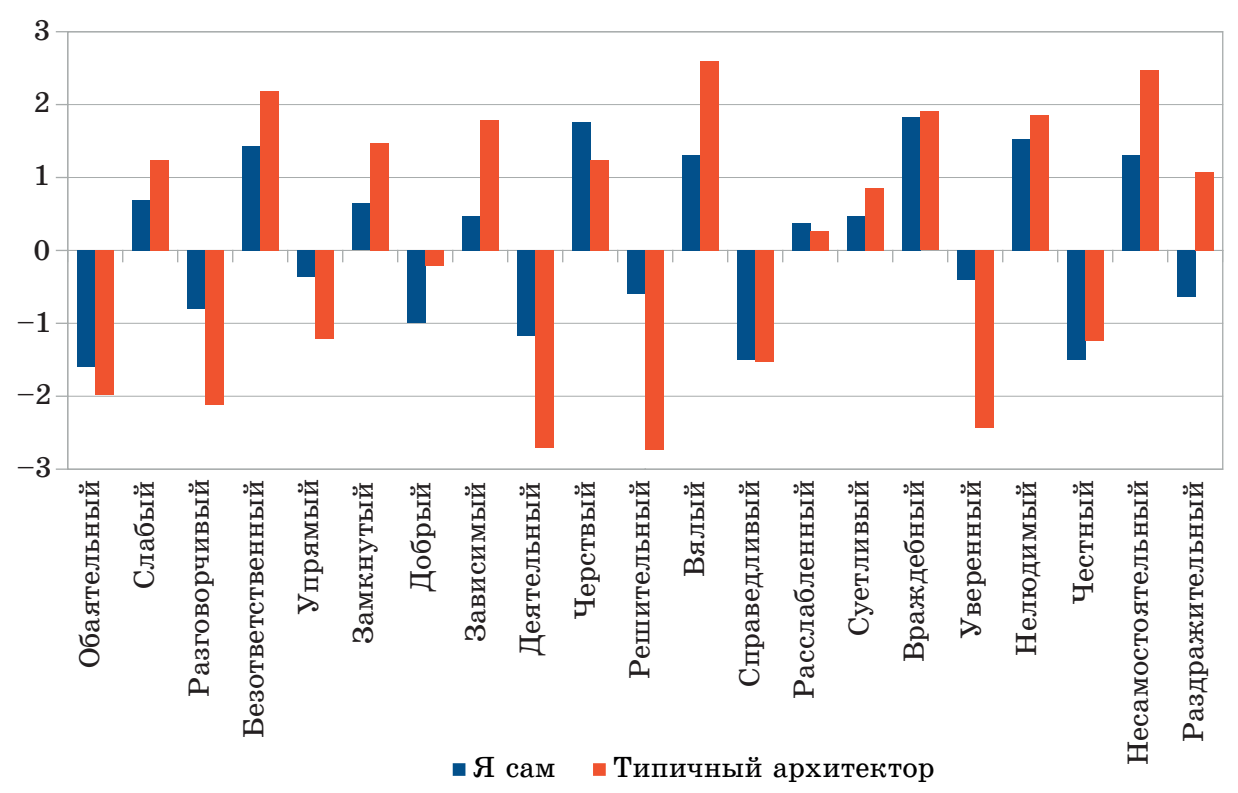

Рис. З. Образ себя и типичного архитектора у студентов направления подготовки «Архитектура»

Так было выявлено 14 шкал (из 21) со значимыми различиями: разговорчивый, ответственный, открытый, независимый, деятельный, решительный, энергичный, уверенный, самостоятельный, раздражительный-невозмутимый $(0,01$ уровень значимости) и сильный, упрямый, добрый, отзывчивый $(0,05$ уровень значимости). Причем, студенты считают себя добрее и отзывчивее типичного архитектора. Однако, по другим шкалам, где были обнаружены значимые различия превосходство за «Типичным архитектором». В целом образы сохраняют свою позитивность. Таким образом, первая гипотеза на выборке студентов направления архитектуры не получила свое подтверждение.

Результаты оценки студентами государственного и муниципального управления образа себя и типичного государственного служащего демонстрирует рис. 4. Общая картина аналогична предыдущим выборкам: содержание шкал идентично за исключением показателей по шкале «раздражительность-невозмутимость». Студенты считают себя раздражительными, а госслужащих невозмутимыми. При проверке различий по представленным шкалам на предмет значимых при помощи U-критерия Манна-Уитни было выявлено семь шкал (из 21) со значимыми различиями. Ими стали: обаятельность, сила, доброта, деятельность, решительность, уверенность, раздражительность-невозмутимость ( 0,01 уровень значимости). В целом образ себя и типичного государственного служащего оцениваются позитивно. Таким образом, первая гипотеза на выборке студентов государственного и муниципального управления получила свое подтверждение.

\section{Baikal Research Journal}




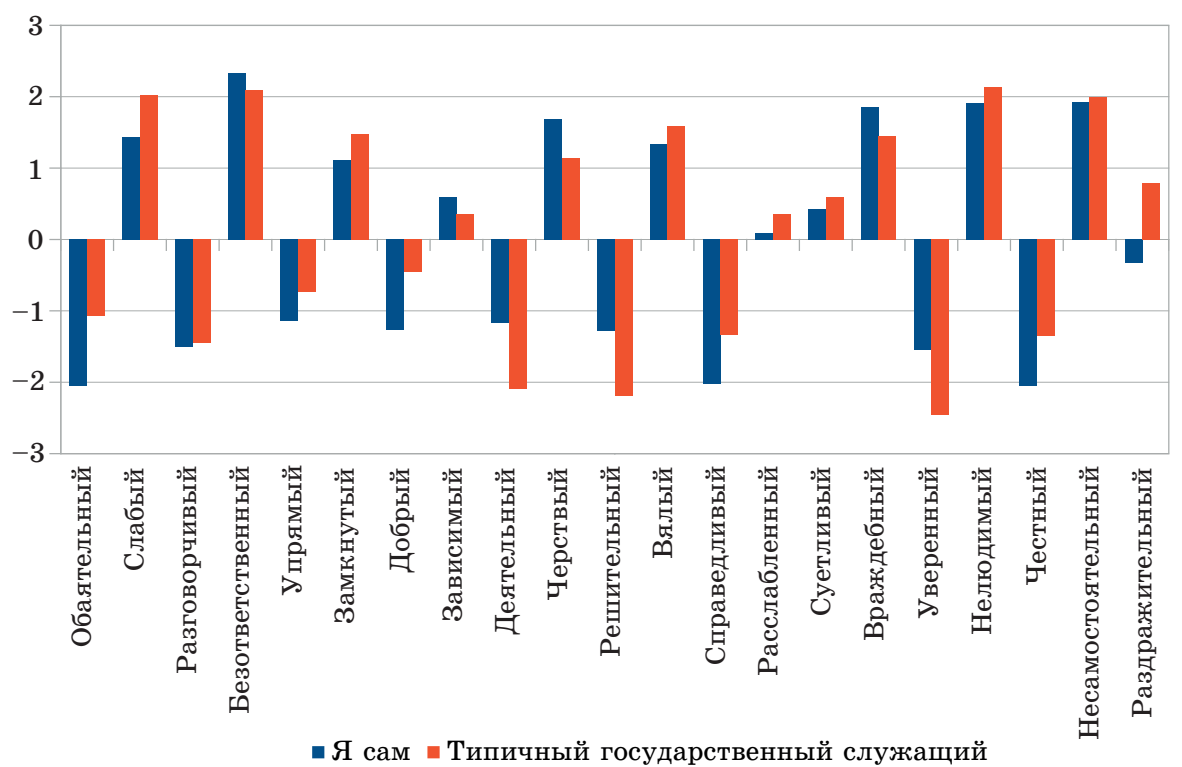

Рис. 4. Образ себя и типичного госслужащего у студентов направления подготовки «Государственное и мунииипальное управление»

Для проверки второй гипотезы респондентам было предложено оценить типичных представителей четырех других профессий, кроме названных профессий студенты также оценивали еще и представления о «типичном враче». Результаты представлены в табл. 1-4.

В табл. 1 показаны названия шкал и уровни значимости в оценке студентами прикладной информатики типичных представителей иных профессий и себя.

Таблица 1

Шкалы и уровни значимости в оценке студентами прикладной информатики типичных представителей иных профессий и себя

\begin{tabular}{|c|c|c|c|c|}
\hline $\begin{array}{c}\text { Уровень } \\
\text { значимости }\end{array}$ & Логист & Архитектор & $\begin{array}{c}\text { Государственный } \\
\text { служащий }\end{array}$ & Врач \\
\hline 0,05 & $\begin{array}{l}\text { Решительность } \\
\text { Невозмутимость }\end{array}$ & $\begin{array}{l}\text { Доброта } \\
\text { Решительность } \\
\text { Энергичность }\end{array}$ & Суетливость & $\begin{array}{l}\text { Разговорчивость } \\
\text { Справедливость } \\
\text { Общительность } \\
\text { Невозмутимость }\end{array}$ \\
\hline 0,01 & $\begin{array}{l}\text { Открытость } \\
\text { Доброта } \\
\text { Отзывчивость } \\
\text { Справедливость } \\
\text { Суетливость } \\
\text { Уверенность } \\
\text { Честность }\end{array}$ & $\begin{array}{l}\text { Ответственность } \\
\text { Открытость } \\
\text { Деятельность } \\
\text { Справедливость } \\
\text { Уверенность } \\
\text { Честность } \\
\text { Невозмутимость }\end{array}$ & $\begin{array}{l}\text { Разговорчивость } \\
\text { Ответственность } \\
\text { Замкнутость } \\
\text { Эгоизм } \\
\text { Черствость } \\
\text { Несправедливость } \\
\text { Враждебность } \\
\text { Уверенность } \\
\text { Неискренность }\end{array}$ & $\begin{array}{l}\text { Ответственность } \\
\text { Упрямство } \\
\text { Открытость } \\
\text { Решительность } \\
\text { Уверенность }\end{array}$ \\
\hline Bсего & 9 шкал & 10 шкал & 10 шкал & 9 шкал \\
\hline
\end{tabular}

Количество шкал, имеющих значимые отличия в образах иных профессий у студентов прикладной информатики, не отличается от сравнения себя с представителем своей профессии. Логист представляется респондентам как более решительный, невозмутимый, открытый, суетливый, уверенный. Однако, типичный логист уступает им в доброте, отзывчивости, справедливости, честности.

\section{Baikal Research Journal}


Типичный архитектор студентами прикладной информатики представляется как более ответственный, открытый, деятельный, решительный, энергичный, уверенный, невозмутимый. Сами же они превосходят архитектора в доброте, справедливости и честности.

Государственный служащий в представлении студентов прикладной информатики более разговорчив, открыт, суетлив, уверен, чем они сами. Образ государственного служащего имеет ряд негативных характеристик: эгоизм, черствость, несправедливость, враждебность, неискренность. Сами же студенты, по их мнению, лишены этих качеств и являются добрыми, отзывчивыми, справедливыми, дружелюбными и искренними.

Образ врача у респондентов предстает нам как превосходящий в разговорчивости, ответственности, открытости, решительности, уверенности, общительности, невозмутимости. Сами себя студенты прикладной информатики в сравнении с врачом считают упрямее и справедливее.

В целом образы других профессий в восприятии студентов прикладной информатики имеют позитивную точку рассмотрения. Однако, типичный госслужащий имеет ряд негативных качеств. Вторая гипотеза не нашла подтверждения в этой выборке.

В табл. 2 показаны названия шкал и уровни значимости в оценке студентами логистики и менеджмента на транспорте типичных представителей иных профессий и себя.

Таблица 2

Шкалы и уровни значилости в оценке студентали логистики и менеджлента на транспорте типичных представителей иных профессий и себя

\begin{tabular}{|c|c|c|c|c|}
\hline $\begin{array}{c}\text { Уровень } \\
\text { значимости }\end{array}$ & Информатик & Архитектор & Госслужащий & Врач \\
\hline 0,05 & Уверенность & $\begin{array}{l}\text { Открытость } \\
\text { Уверенность }\end{array}$ & $\begin{array}{l}\text { Обаятельность } \\
\text { Невозмутимость }\end{array}$ & Упрямство \\
\hline 0,01 & $\begin{array}{l}\text { Обаятельность } \\
\text { Сила } \\
\text { Молчаливость } \\
\text { Замкнутость } \\
\text { Отзывчивость } \\
\text { Энергичность } \\
\text { Справедливость } \\
\text { Спокойствие } \\
\text { Нелюдимость } \\
\text { Невозмутимость }\end{array}$ & \begin{tabular}{|l} 
Деятельность \\
Решительность \\
Справедливость \\
Невозмутимость
\end{tabular} & $\begin{array}{l}\text { Разговорчивость } \\
\text { Ответственность } \\
\text { Эгоизм } \\
\text { Деятельность } \\
\text { Черствость } \\
\text { Решительность } \\
\text { Справедливость } \\
\text { Напряженность } \\
\text { Суетливость } \\
\text { Дружелюбие } \\
\text { Уверенность } \\
\text { Честность }\end{array}$ & $\begin{array}{l}\text { Решительность } \\
\text { Невозмутимость }\end{array}$ \\
\hline Bcero & 11 шкал & 6 шкал & 14 шкал & 3 шкалы \\
\hline
\end{tabular}

Как можно увидеть респонденты направления логистики и менеджмента на транспорте в оценке типичного информатика и государственного служащего представляют их отличными от себя по большему числу шкал методики Осгуда. Типичный информатик, по их мнению, более спокойный и невозмутимый. Однако, по оставшимся 9 шкалам студенты превосходство оставляют за собой.

В отношении представления о государственном служащем участники опроса также, как и в предыдущей выборке считают его злым, черствым, суетливым и напряженным, более разговорчивым, деятельным, решительным, уверенным, невозмутимым. Себя же студенты считают добрыми, отзывчивыми, спокойными, расслабленными и обаятельнее, ответственнее, справедливее, дружелюбнее, честнее чем типичный госслужащий. Также по шкале «Честный-Неискренний» образ

\section{Baikal Research Journal}


госслужащего в этой выборке набрал значение 0 . То есть респонденты не смогли однозначно дать ответ по этим качествам. Скорее всего это связано с небольшим объемом выборки и спецификой конкретного года набора.

В отношении врача значимых отличий по шкалам методики было обнаружено всего 3. Образ врача оказался менее упрям, более решителен и невозмутим.

Представления о типичном архитекторе выразились в значимых различиях по шести шкалам. По ним архитектор превосходит респондентов в открытости, деятельности (как уровне активности), решительности, уверенности, невозмутимости, но уступает им в справедливости.

В целом образы других профессий у студентов логистики и менеджмента на транспорте позитивные. Вторая гипотеза на этой выборке частично нашла подтверждение.

В табл. 3 показаны названия шкал и уровни значимости в оценке студентами направления архитектуры типичных представителей иных профессий и себя.

Таблица 3

Шкалы и уровни значимости в оценке студентами направления архитектуры типичных представителей иных профессий и себя

\begin{tabular}{|c|c|c|c|c|}
\hline $\begin{array}{c}\text { Уровень } \\
\text { значимости }\end{array}$ & Информатик & Логист & Госслужащий & Врач \\
\hline 0,05 & Справедливость & $\begin{array}{l}\text { Сила } \\
\text { Расслабленность }\end{array}$ & $\begin{array}{l}\text { Сила } \\
\text { Открытость } \\
\text { Деятельность } \\
\text { Суетливость }\end{array}$ & Расслабленность \\
\hline 0,01 & $\begin{array}{l}\text { Непривлекательность } \\
\text { Молчаливость } \\
\text { Замкнутость } \\
\text { Отзывчивость } \\
\text { Энергичность } \\
\text { Дружелюбие } \\
\text { Нелюдимость } \\
\text { Невозмутимость }\end{array}$ & $\begin{array}{l}\text { Обаятельность } \\
\text { Ответственность } \\
\text { Отзывчивость } \\
\text { Решительность } \\
\text { Уверенность } \\
\text { Невозмутимость }\end{array}$ & $\begin{array}{l}\text { Разговорчивость } \\
\text { Эгоизм } \\
\text { Отзывчивость } \\
\text { Решительность } \\
\text { Дружелюбие } \\
\text { Уверенность } \\
\text { Общительность } \\
\text { Неискренность } \\
\text { Самостоятельность } \\
\text { Невозмутимость }\end{array}$ & $\begin{array}{l}\text { Обаятельность } \\
\text { Открытость } \\
\text { Решительность } \\
\text { Уверенность } \\
\text { Невозмутимость }\end{array}$ \\
\hline Bcero & 9 шкал & 8 шкал & 14 шкал & 6 шкал \\
\hline
\end{tabular}

У студентов направления архитектуры значимые различия по большинству шкал методики личностного дифференциала Осгуда были выявлены только при анализе образа государственного служащего. Типичный государственный служащий, по их мнению, суетлив, эгоистичен, неискренен, однако превосходит респондентов в силе, разговорчивости, открытости, деятельности (как уровне активности), решительности, уверенности, общительности, самостоятельности и невозмутимости. Сами же студенты считают себя спокойными, добрыми, честными и отзывчивее, дружелюбнее, чем типичный госслужащий.

Согласно полученным данным, типичный информатик превосходит респондентов в невозмутимости. Участники исследования считают его непривлекательным, молчаливым, замкнутым, нелюдимым. Себя же он и видят обаятельными, разговорчивыми, открытыми, общительными и более отзывчивыми, энергичными, дружелюбными, справедливыми.

Типичный логист в представлении студентов направления архитектуры более сильный, ответственный, решительный, уверенный и невозмутимый. Он расслаблен, а сами студенты напряжены. Однако, превосходят логиста в обаянии и отзывчивости.

Представления о типичном враче по предложенным шкалам выявили значимую разницу по шести из 21. Врач превосходит студентов по открытости, решительно-

\section{Baikal Research Journal}


сти, уверенности, он расслаблен и невозмутим. Респонденты же, оценивая себя, считают, что они обаятельнее чем типичный врач, напряжены и раздражительны.

В целом представления респондентов этой группы о представителях других выбранных нами профессий позитивны. Вторая гипотеза подтвердилась только в отношении образа государственного служащего.

В табл. 4 показаны названия шкал и уровни значимости в оценке студентами государственного и муниципального управления типичных представителей иных профессий и себя.

Таблица 4

Шкалы и уровни значимости в оценке студентами государственного и мунищипального управления типичных представителей иных профессий и себя

\begin{tabular}{|c|c|c|c|c|}
\hline $\begin{array}{c}\text { Уровень } \\
\text { значимости }\end{array}$ & Информатик & Логист & Архитектор & Врач \\
\hline 0,05 & Спокойствие & $\begin{array}{l}\text { Разговорчивость } \\
\text { Доброта } \\
\text { Деятельность } \\
\text { Суетливость } \\
\text { Дружелюбие }\end{array}$ & - & Справедливость \\
\hline 0,01 & $\begin{array}{l}\text { Непривлекательность } \\
\text { Слабость } \\
\text { Молчаливость } \\
\text { Уступчивость } \\
\text { Замкнутость } \\
\text { Отзывчивость } \\
\text { Решительность } \\
\text { Вялость } \\
\text { Справедливость } \\
\text { Дружелюбие } \\
\text { Нелюдимость } \\
\text { Честность } \\
\text { Невозмутимость }\end{array}$ & $\begin{array}{l}\text { Обаятельность } \\
\text { Зависимость } \\
\text { Отзывчивость } \\
\text { Энергичность } \\
\text { Справедливость } \\
\text { Честность } \\
\text { Невозмутимость }\end{array}$ & $\begin{array}{l}\text { Независимость } \\
\text { Деятельность } \\
\text { Решительность } \\
\text { Энергичность } \\
\text { Справедливость } \\
\text { Честность } \\
\text { Невозмутимость }\end{array}$ & $\begin{array}{l}\text { Обаятельность } \\
\text { Решительность } \\
\text { Невозмутимость }\end{array}$ \\
\hline Всего & 14 шкал & 12 шкал & 7 шкал & 4 шкалы \\
\hline
\end{tabular}

Согласно нашим данным, представления о других профессиях у студентов государственного и муниципального управления в сравнении с образом себя по большинству шкал сравнения различны в отношении типичного информатика и логиста. Так типичный информатик непривлекателен, слаб, молчалив, уступчив, замкнут, вял, нелюдим и невозмутим, и превосходит респондентов этой группы в спокойствии. Сами же студенты оценивают себя как обаятельных, сильных, разговорчивых, упрямых, открытых, энергичных, общительных и раздражительных. В тоже время превосходят типичного информатика в отзывчивости, решительности, справедливости, дружелюбии и честности.

Оценка образа типичного логиста показывает, что образ логиста воспринимается как зависимый, суетливый, невозмутимый и превосходит образ «Я сам» респондентов в деятельности (как уровне активности), энергичности. В свою очередь себя участники исследования оценивают как независимых, спокойных, раздражительных, и обаятельнее, разговорчивее, добрее, отзывчивее, справедливее, доброжелательнее, честнее нежели типичный логист.

Типичный архитектор оценивается студентами государственного и муниципального управления как более независим, деятелен, решителен, энергичен, невозмутим, но менее справедлив и честен чем они сами.

Типичный врач в целом очень похож на самих респондентов данной группы, однако он более решителен и невозмутим. А сами студенты раздражительны, обаятельнее и справедливее.

\section{Baikal Research Journal}


В целом образы представителей других профессий позитивны. Вторая гипотеза частично подтвердилась.

Обсуждение результатов и выводы. Вопрос формирования профессиональной идентичности представляется критичным для получения квалифицированных кадров. На каком этапе развития человек должен приобрести профессиональную идентичность? И какова роль профессионального (и высшего, и среднего) образования в этом процессе? Какая степень «доводки» выпускника должна считаться допустимой на конкретном трудовом посту? Вопросы эти не досужего характера. Они соприкасаются с темой оценки качества образовательной среды, затратами государства на подготовку специалистов. На настоящий момент нет четких ответов на поставленные вопросы, и мы в формулировке гипотез сделали предположения без опоры на такие требования. Таким образом, исследование стало констатирующим положение дел. Мы получили что, соотношение количества шкал со значимыми различиями образа «Я сам» и образов типичных представителей своей и иных профессий не показало каких-то явных векторов в оценке. Можно сказать, что образ «Я сам» скорее равноудален от всех оцениваемых респондентами профессий. Исследованная нами выборка студентов третьего курса бакалавриатуры дает основания предположить, что идентичность участников исследования на момент исследования строится не столько по профессиональному вектору развития, а скорее по социальному. То есть идентификация себя идет скорее, как «студент» нежели как «представитель профессии».

\section{Список использованной литературы}

1. Стефаненко Т. Г. Этническая идентичность и некоторые проблемы ее изучения / Т. Г. Стефаненко // Этнос. Идентичность. Образование : тр. по социологии образования / под ред. В. С. Собкина. - М. : Центр социологии образования Рос. акад. образования, 1998. - С. 84-104.

2. Лукьянов О. В. Проблема становления идентичности в эпоху социальных изменений / О. В. Лукьянов. - Томск : Изд-во Том. гос. ун-та, 2008. - 212 с.

3. Бохан Т. Г. Проблемы становления идентичности у подростков и юношей при формировании пивной аддикции / Т. Г. Бохан, Н. В. Твердохлебова // Вестник Томского государственного педагогического университета. - 2012. - № 6 (121). - C. 126-130.

4. Kelly G. A. The psychology of personal constructs. - New York : Norton, 1955. Vol. 1: A theory of personality.

5. Kelly G. A. The psychology of personal constructs. - New York : Norton, 1955. Vol. 2: Clinical diagnosis and personality.

6. Поваренков Ю. П. Психологическая характеристика профессиональной идентичности. Кризис идентичности и проблемы становления гражданского общества / Ю. П. Поваренков // Кризис идентичности и проблемы становления гражданского общества : сб. науч. тр. - Ярославль : Ярослав. гос. пед. ун-т, 2003. - С. 154-163.

7. Климов Е. А. Психология профессионала / Е. А. Климов. - М. : Ин-т практ. психологии ; Воронеж : МОДЭК, 1996. - 400 с.

8. Шнейдер Л. Б. Профессиональная идентичность / Л. Б. Шнейдер. - М. : Моск. открыт. соц. ун-т, 2001. - 272 с.

9. Ермолаева Е. П. Профессиональная идентичность и маргинализм: концепция и реальность (ст. 1) / Е. П. Ермолаева // Психологический журнал. - 2001. - Т. 22, № 4. C. $51-59$.

10. Иванова Н. Л. Профессиональная идентичность и профессиональное пространство / Н. Л. Иванова, Е. В. Конева // Мир психологии. - 2004. - № 2. - С. 148-156.

11. Трофимова Е. Л. Особенности профессионального самоопределения студентов-психологов / Е. Л. Трофимова // Ученые записки Забайкальского государственного университета. Сер. Педагогика и психология. - 2011. - № 5 (40). - С. 199-204.

12. Фетискин Н. П. Социально-психологическая диагностика развития личности и малых групп / Н. П. Фетискин, В. В. Козлов, Г. М. Мануйлов. - М. : Изд-во Ин-та психотерапии и клинической психологии, 2002. $-490 \mathrm{c.}$

\section{Baikal Research Journal}




\section{References}

1. Stefanenko T. G. Ethnical identity and some problems of studying it. In Sobkin V. S. (ed.). Etnos. Identichnost'. Obrazovanie. Trudy po sotsiologii obrazovaniya [Ethnos. Identity. Education. Works on sociology of education]. Moscow, Centre for Sociology of Education of Russian Academy of Education Publ., 1998, pp. 84-104. (In Russian).

2. Lukyanov O. V. Problema stanovleniya identichnosti $v$ epokhu sotsial'nykh izmenenii [Problems of establishing identity during times of social changes]. Tomsk State University Publ., 2008. 212 p.

3. Bokhan T. G., Tverdokhlebova N. V. Problems of establishing teenagers' and youth identity in developing beer addiction. Vestnik Tomskogo gosudarstvennogo pedagogicheskogo universiteta $=$ Tomsk State Pedagogical University Bulletin, 2012, no. 6 (121), pp. 126-130. (In Russian).

4. Kelly G. A. The Psychology of Personal Constructs. New York, Norton, 1955. Vol. 1. A theory of personality.

5. Kelly G. A. The Psychology of Personal Constructs. New York, Norton, 1955. Vol. 2. Clinical diagnosis and personality.

6. Povarenkov Yu. P. Psychological characteristic of professional identity. Crisis of identity and problems of establishing civil society. Krizis identichnosti i problemy stanovleniya grazhdanskogo obshchestva [Crisis of identity and problems of establishing civil society, Yaroslavl State Pedagogical University Publ., 2003, pp. 154-163. (In Russian).

7. Klimov E. A. Psikhologiya professionala [Psychology of the professional]. Moscow, Institute of Psychotherapy Publ., Voronezh, MODEK Publ., 1996. 400 p.

8. Shneider L. B. Professional'naya identichnost' [Professional identity]. Moscow Open Social University Publ., 2001. 272 p.

9. Ermolayeva E. P. Professional identity and marginalism: concept and reality (art. 1) Psikhologicheskii zhurnal = Psychology Journal, 2001, vol. 22, no. 4, pp. 51-59. (In Russian).

10. Ivanova N. L., Koneva E. V. Professional identity and professional space. Mir psik hologii $=$ World of psychology, 2004, no. 2, pp. 148-156. (In Russian).

11. Trofimova E. L. Peculiarities of psychology of students' professional self-determination. Uchenye zapiski Zabaikal'skogo gosudarstvennogo universiteta. Seriya Pedagogika i psikhologiya = Scholarly Notes of Zabaikalye State University. Series Pedagogy, Psychology, 2011, no. 5 (40), pp. 199-204. (In Russian).

12. Fetiskin N. P. Sotsial'no-psikhologicheskaya diagnostika razvitiya lichnosti $i$ malykh grupp [Socio-psychological diagnosis of developing personality and small groups]. Moscow, Institute of Psychotherapy and Clinical Psychology Publ., 2002. 490 p.

\section{Информация об авторах}

Мунгалов Владилир Николаевич - кандидат психологических наук, доцент, кафедра социальной и экономической психологии, социологии и социальной работы, Байкальский государственный университет, 664003, г. Иркутск, ул. Ленина, 11, e-mail: kham@inbox.ru.

Левина Ася Георгиевна - бизнес-тренер АО «Банк Русский Стандарт», 664025, г. Иркутск, ул. 5-й Армии, 29, e-mail: asti_levin@mail.ru.

\section{Authors}

Vladimir N. Mungalov - PhD in Psychology, Associate Professor, Chair of Social and Economic Psychology, Sociology and Social Work, Baikal State University, 11 Lenin St., 664003, Irkutsk, Russian Federation; e-mail: kham@inbox.ru.

Asya G. Levina - Business Couch, AS «Bank Russian Standard», 29 5-th Army St., 664025, Irkutsk, Russian Federation; e-mail: asti_levin@mail.ru.

\section{Библиографическое описание статьи}

Мунгалов В. Н. Профессиональная идентичность студентов, получающих профессиональное образование (на примере высшего образования) / В. Н. Мунгалов, А. Г. Левина // Baikal Research Journal. - 2016. — T. 7, № 6. — DOI: 10.17150/2411-6262.2016.7(6).24.

\section{Reference to article}

Mungalov V. N., Levin A. G. Professional identity of students obtaining higher professional education. Baikal Research Journal, 2016, vol. 7, no. 6. DOI: 10.17150/2411-6262.2016.7(6).24. (In Russian).

\section{Baikal Research Journal}

